\title{
Taxonomic Studies of Ciona intestinalis (L.) and Its Allies
}

$\operatorname{AUTHOR}(\mathrm{S})$ :

Hoshino, Zen-ichiro; Nishikawa, Teruaki

\section{CITATION:}

Hoshino, Zen-ichiro ... [et al]. Taxonomic Studies of Ciona intestinalis (L.) and Its Allies. PUBLICATIONS OF THE SETO MARINE BIOLOGICAL LABORATORY 1985, 30(1-3): 61-79

ISSUE DATE:

1985-06-30

URL:

http://hdl.handle.net/2433/176100

RIGHT: 


\title{
Taxonomic Studies of Ciona intestinalis (L.) and Its Allies
}

By

\section{Zen-ichiro Hoshino}

Department of Biology, Faculty of Education, Iwate University, Morioka, 020, Japan

and

\section{Teruaki Nishikawa}

Biological Laboratory, College of General Education, Nagoya University, Nagoya, 464, Japan

With Text-figures $1-4$

\begin{abstract}
The two species of the genus Ciona, C. robusta Hoshino et Tokioka and C. intestinalis (Linné) sensu Hoshino \& Tokioka, 1967 from the Japanese waters are consistently distinguishable from each other by several minor but distinct features. On the other hand, the survey of literature and examination of many specimens collected from various localities in different years proved that European waters, the type locality of $C$. intestinalis, have been inhabited only by a single species indistinguishable morphologically from $C$. robusta. Thus, robusta should be regarded as a junior synonym of intestinalis. Further, it was also proved that $C$. intestinalis sensu Hoshino \& Tokioka should be referred to G. savignyi Herdman originally collected off Kobe, Japan, during the Challenger Expedition, by reexamination of the type specimen of this species. In addition, brief references are made to other described species of the genus Ciona.
\end{abstract}

\section{Introduction}

Although a considerable number of species have been described in the genus Ciona, the specific criteria in separating respective species one another are seemingly of minor and rather unstable nature. Therefore, some researchers suggested even that the genus Ciona might be represented by only a single species intestinalis Linné and other described species might be its synonyms (for instance, see Berrill, 1950, p. 129). In such circumstances, it caused great excitement of the first author to find that there were two distinct forms of Ciona in the Japanese waters, that were separable consistently from each other by existence or absence of the endostylar appendage and by situation of the pharyngeo-epicardiac openings. Further, the test is always soft gelatinous in one form, while in the other it may be soft but very often considerably hard and cartilaginous as in some styelids. As these forms had been used widely and together as the material in various physiological and biological studies, it was urged

Publ. Seto Mar. Biol. Lab., 30(1/3), 61-79, $1985 . \quad$ (Article 3) 
to describe these distinctively. Thus, in collaboration with Dr. Tokioka of the Seto Marine Biological Laboratory, the first author defined the form, with the test always soft, without the endostylar appendage, and with the pharyngeo-epicardiac openings close to the oesophageal opening, as C. intestinalis and the other, often with much harder test, with the endostylar appendage, and with the pharyngeo-epicardiac openings near the appendage, as a new species C. robusta (Hoshino \& Tokioka, 1976). This was quite of a provisional nature, because the real figure of $C$. intestinalis described by Linné, checked at the same level of exactness as in separating these two Japanese forms, could not be recognized by the authors, for enough references and specimens of $C$. intestinalis from European waters were inaccessible to them at that time. The identification of the Japanese form with the test always soft with intestinalis was made only on the recognition of the authors, that the test of intestinalis is generally soft gelatinous in European waters. The definite conclusion of the taxonomic problem was, thus, left to the specialists in Europe at that time.

On the other hand, the distinction between these two forms has been proved in some other features else than morphology. For instance, it has been noticed embryologically (Pisanó \& Rengel, 1972; but also see Rosati \& De Santis, 1978), physiologically (Michibata \& Yamazaki, 1981; Michibata, 1984) or biologically (Pisanó, Rengel \& Bustuoabad, 1971; Nakauchi \& Kajiwara, 1978). Thus, it has been urged again to make a final conclusion of the taxonomic problem of these two forms. Then, the first author started to do his efforts to draw the figure of instetinalis of Linné by checking the literature and by examining by his own eyes the specimens of intestinalis deposited at the institutes and museums in Europe and those actually collected by himself in various parts of European waters including type locality of this species (see Linné, 1767, p. 1087). Although the work was no easy, as not types of intestinalis remain at present and the specimens ever examined by Linné himself are entirely lost, the results revealed that European waters are inhabited by only a single form morphologically indistinguishable from C. robusta, namely intestinalis of Linné should be the same as $C$. robusta, and then robusta is to be a junior synonym of intestinalis.

Meanwhile, the last author was imposed to check the other species of the genus Ciona, else than intestinalis and began his researches mainly through the literature and reexamination of the specimens of described species of the genus Ciona as many as possible, that were still available at the institutes and museums in the world. And careful observation of the type specimen of $C$. savignyi Herdman, 1882 collected from off Kobe, Japan during the Challenger Expedition and deposited in the British Museum (Natural History) revealed that C. intestinalis sensu Hoshino \& Tokioka, 1967 was quite the same as savignyi, thus the former should sink as a synonym of the latter.

The real taxonomic status of the two Japanese species of Ciona thus cleared has been published already but briefly at the 54th annual meeting of the Zoological Society of Japan (Hoshino \& Nishikawa, 1983). However, the present studies seemingly show not only the taxonomic morphology of $C$. intestinalis more exactly than ever made, by comparing it with those of other species of the genus, but also the 
actual existence of other valid species else than intestinalis in the genus Ciona. Thus, the present paper is prepared to give the full taxonomic data of C. intestinalis and C. savignyi, but the references are to be made as far as possible to other described species in the course of taxonomic discussion of the two species.

In describing the collections of ascidians of various museums and institutes, they are abbreviated as follows:

AMNH, American Museum of Natural History; BMNH, British Museum (Natural History); HM, Hancock Museum; MNHN, Muséum National d'Histoire Naturelle; NMNH, National Museum of Natural History, Smithsonian Institution; $\mathbf{O C}$, Oka Collection deposited in the University of Tsukuba; SMBL, Seto Marine Biological Laboratory, Kyoto University; SMNH, Swedish Museum of Natural History; TMBS, Trondheim Marine Biological Station, University of Trondheim; ZMB, Zoological Museum, University of Bergen; ZMK, Zoologiske Museum, K $\phi$ benhavn.

\section{Ciona intestinalis (Linné, 1767)}

$$
\text { (Fig. 1, A-C; Figs. } 2 \text { and 4) }
$$

Limited synonymy: Numerous references have been made to "Ciona intestinalis", as well as to its various synonyms, but the majority lack information enough to identify precisely the therein described specimens with intestinalis defined here. Below listed are only the references having clear descriptions (and/or figures) as to the diagnostic characters such as the endostylar appendage (EA) and/or the pharyngeo-epicardiac openings (PO), and those containing the descriptions of the specimens later reexamined (RE) and identified obviously by the present authors with this species.

Ciona intestinalis -Kuppfer, 1875, p. 207 (North Sea and Baltic Sea, 10-50 fathoms, 1871-72; EA, PO); Heller, 1875, pp. 117-120, pl. 3, figs. 8-9, pls. 4-5 (Adriatic Sea; EA); Traustedt, 1882, pp. 454-455, pl. 33, figs. 3-5, pl. 34, fig. 2, pl. 35, figs. 1-2 (Naples, 1882; EA, PO); Roule, 1884, pp. 7-257, pls. 1-12, pl. 13, fig. 81 (Provence, Mediterranean; EA); Damas, 1899, pp. 1-25, pls. 1-3 (Naples and Belgian coast, 1885-86; EA, PO); Hartmeyer, 1903, pp. 297-301 (at least in part; Norway; RE); 1915, p. 321 (British waters; RE); Alder \& Hancock, 1907, pp. 9-14, pl. 21, figs. 1-5, text-fig. 28 (at least in part; British waters; RE); Michaelsen, 1923, p. 37 (Rio de Janeiro, Brazil; RE); Millar, 1953, pp. 1-122, pls. 1-19, text-figs. 1-9 (British waters; EA, PO); 1963, p. 720 (Australia; RE).

Ciona intestinalis f. iypica -Hartmeyer, 1924, pp. 90-98 (at least in part; Greenland and the Faroes; RE); Ärnbäck-Christie-Linde, 1934, pp. 15-24 (at least in part; Norway, North Sea, Baltic Sea and Western coast of Sweden; RE).

Ciona intestinalis form "tenella" —Van Name, 1945, p. 163 (at least in part; East Port, Maine; RE). Ciona intestinalis forma costata-Millar, 1970, pp. 114-115, fig. 13 (Argentina; RE).

Ascidia intestinalis -Linné, 1767, p. 1087 (see Discussion below); Cuvier, 1815, pp. 32-33, pl. 2, figs. 4-7 (probably northern coast of France; EA).

Phallusia intestinalis - Savigny, 1816, pp. 107-109, 169-170, pl. 11, figs. 1.1-1.f (probably Mediterranean coast of Egypt; EA).

Ciona canina -Kuppfer, 1875, pp. 206-207, pl. 5, figs. 8-9 (Inner half of Baltic Sea, 1871-72; EA, PO); Traustedt, 1880, pp. 432-434 (at least in part; Denmark; RE).

Ascidia canina -Kuppfer, 1870, pp. 115-172, pls. 8-10 (Kiel Bay; EA).

Ciona fascicularis - Hancock, 1870, pp. 364-365 (Ireland; RE); Kuppfer, 1875, pp. 207-208, pl. 5, fig. 10 (Baltic Sea, 0-1 fathom, 1871-72; EA, PO); Alder \& Hancock, 1907, pp. 15-18, pl. 22, figs. 1-8, text-fig. 29 (Ireland; RE); Hartmeyer, 1915, p. 321 (do.).

Ciona pulchella -Alder \& Hancock, 1907, pp. 14-15, pl. 21, figs. 6-8 (at least in part; Channel 
Islands; RE); Hartmeyer, 1915, p. 321 (do.).

Ascidia pulchella -Alder, 1863, p. 157 (at least in part; Channel Islands; RE).

Ciona robusta --Hoshino \& Tokioka, 1967, pp. 275-290, figs. 1-5, fig. 6 (right), fig. 8 (right), pl. 7

(Onagawa, Miyagi); Pisanó, Rengel \& Bustuoabad, 1971, pp. 1-10, figs. 2-5, 7, 10 (Mar

del Plata, Argentina; EA, PO); 1972, pp. 179-183, figs. 2, 4. (do.); Nishikawa, 1980, tab. 1

(Tanabe Bay).

Ciona gelatinosa (?) —Monniot, 1969, pp. 1133, 1135, fig. 1, a-c (Bay of Biscay; RE).

?Ciona intestinalis var. sydneiensis -Kesteven, 1909, pp. 282-285, pl. 27, figs. 13-19 (Sydney; see Remarks below).

?Ciona intestinalis -Brewin, 1950, pp. 347-349, fig. 2 (New Zealand; see Remarks below).

Material examined:

Europe (arctic waters). Greenland, date unknown, Möller leg.; ZMK; 20 spec.; described by Hartmeyer (1924), as well as probably by Traustedt (1880). Denmark Strait, Ingolf St. 9, $64^{\circ} 18^{\prime} \mathrm{N}$ and $27^{\circ} \mathrm{W}, 295$ fathoms, WT $5.8^{\circ} \mathrm{C}$, May 20, 1895; ZMK; 1 spec.; described by Hartmeyer (1924).

Europe (boreal waters). Norway: SMNH; described by Ärnbäck-Christie-Linde (1934); Grötsund, Finmarken, 126 m, Oct., 1861, No. 396, 4 spec.; Karlsö, Finmarken, 54-72 m, June 13, 1864, No. 1894, 1 spec.; Kristiansand, 90 m, May 9, 1871, No. 829, 1 spec.; Ekersund, 90-108 m, Oct. 22, 1872, No. 334, 1 spec.; Off Jaedersen, 180-270 m, 1874, No. 359, 1 spec.; NW of Bergen, 160-300 m, 1878, No. 391, 1 spec. Norway: Moskenströmmen, 90 m, ZMB No. 16011, 1 spec., described by Hartmeyer (1903); Tysfjord, $500 \mathrm{~m}$, Mar. 28, 1899, ZMB No. 8578, 1 spec., do.; Florö, BMNH No. 1898-5-7-300, as Ciona sp., 1 spec.; Borgenfjorden C4, July 5, 1968, 11 m, TMBS, 2 spec.; Trondheimsfjorden Fänes (St. 72087, Flagruunem), June 29, 1972, 15-25 m, TMBS, 2 spec.; Locality unknown, gr. 225, 19??, TMBS, 2 spec.; Bergen, on ship, MNHN No. P1-CIO-11, 5 spec.; Trondheim, shallow waters and aquarium (WT $8-10^{\circ} \mathrm{C}$ ), Sept. 12, 1974, Hoshino coll., 6 spec. Faroes Islands: ZMK; described by Hartmeyer (1924); Thorshavn, Sept. 20, 1887, 1 spec.; Southern end of Nolso, 80 fathoms, June 20, 1899, 1 spec.; Nolso og Ostnos, 100 fathoms, June 9, 1899, I spec.; Trangivaag, Sept. 21, 1887, 1 spec. Off Shetland Islands, "Jutland Reef", 180-216 m, 1873, SMNH No. 304, 6 spec., described by ÄnbäckChristie-Linde (1934).

Europe (cold temperate waters). Western coast of Sweden: SMNH; described by ÄrnbäckChristie-Linde (1934); Koster Fjord, Bohuslän, 10-30 fathoms, 1865, No. 1562, 1 spec.; Ibid., 5-15 fathoms, 1871, No. 1397, 4 spec.; Syd-Koster, 10 fathoms, July 10, 1871, No. 800, 1 spec.; The Sound, Landskrona-Malmö, 10-16 m, July 22, 1878, No. 251, 3 spec.; Hallands Väderö, 18 m, July 15, 1878, No. 258, 4 spec. Denmark: ZMK; Vellerup, Isefjord, 1861, 2 spec., described probably by Traustedt (1880); Cilleleje, 2 spec., do.; Hellebaek, 2 spec., do.; Kalo Vig, 1887, 2 spec.; Hevringholn Flak, June 19, 1888, 2 spec.; Lillebaclt, Aug. 6, 1900, 2 spec.; Dana St. 2852, $56^{\circ} 49^{\prime} \mathrm{N}$ and $6^{\circ} 32^{\prime} \mathrm{E}, 48 \mathrm{~m}$, Oct. 1, 1922, 2 spec. Denmark: Helsingor (Marine Biol. Lab., Univ. of Copenhagen), from the underground tanks, aquarium and West off the laboratory at a depth of $80 \mathrm{~m}$, Sept. 9, 1974; Hoshino coll.; 11 spec. Kattegat or Odensefjord, Denmark; HM No. 2-2-7 and 2-2-8; as Phallirsia canina; 5 spec. and 1 spec. respectively. Western part of Baltic Sea: Kiel or Rügen, date unknown, SMNH No. 1017, 1 spec., described by Ärnbäck-Christie-Linde (1934). British Islands: BMNH; Polperro, Cornwall, No. 1863-427-10, 2 spec.; Plymouth, No. 1896-12-3-14-5, 1 spec.; Loch Tyne, Scotland, No. 1898-5-7296, as Ciona sp., 1 spec.; Clew Bay, Ireland, 1874, No. 1898-5-7-298, 2 spec.; Bertraghboy Bay, Ireland, No. 1898-5-7-299, 1 spec.; Ross-shire, Loch Alsh, No. 1905-1-20-1-2, I spec.; Clew Bay, Ireland, 1874, No. 1911-12-9-5 (part), 2 spec.; Plymouth Mar. Biol. Stat, No. 19134-23-2 and $-3,2$ spec.; Holyhead, N. W. Wales, No. 1916-10-28-8, 1 spec.; Plymouth, No. 1926-9-9-6, 1 spec.; English Channel, St. 43, 118 m, No. 1949-12-29-127, 1 spec.; English Channel, St. 58, 30 m, No. 1949-12-29-129, I spec.; English Channel, St. 73, No. 1949-1229-131, 1 spec.; Among weed on sand, 15 fathoms, SYRA (Cambridge Univ. Exp.), No. 196011-24-2, 1 spec.; SE of Millport, Isle of Cumbrae, $30 \mathrm{~m}$, No. 1964-7-7-5, 1 spec.; Longston Hbr, Portsmouth, No. 1965-7-30-191, 1 spec.; Longston Hbr, Portsmouth, No. 1965-7-30-202- 
205, 1 spec.; Loch Torridon Area, Mouth of Balgy River, Low Water Springs, July 30, 1973, No. 1973-10-3-2, 1 spec. British Islands: HM; Kilkieran Bay, Connemara, Ireland, 1869, No. 1-6-2, as C. fascicularis, 13 spec. out of about 20 were identified with $C$. intestinalis without doubt, described by Hancock (1870), Alder \& Hancock (1907) and Hartmeyer (1915); Hastings, England, No. 2-3-12, as A. intestinalis, 4 spec., reexamined by Hartmeyer (1915); Westport Bay, Ireland, 1871, No. 2-3-13, as C. intestinalis, 4 spec., do.; no data, No. 3-3-2, as $A$. intestinalis, 14 spec.; do., No. 3-3-3, as A. intestinalis, 10 spec.; at least a part of these specimens may probably have been described by Alder \& Hancock (1907). Plymouth, from the underground tank, Sept. 5, 1974, Hoshino coll., 7 spec.

Europe (warm temperate waters). Channel Islands, probably Guernsey, HM No. 4-3-7, as $A$. pulchella, 1 spec., described by Alder (1863), Alder \& Hancock (1907) and Hartmeyer (1915). Guernsey, BMNH No. 1898-5-7-295, 1 spec. Lezardrieux, North France, MNHN No. P1CIO-32, 5 spec. St. Vorst de la. Hoyjue (St. 4c), North France, BMNH No. 1965-7-30-47, 1 spec. Thalassa St. U848, 44 $11,2^{\prime} \mathrm{N}$ and $8^{\circ} 36.8^{\prime} \mathrm{W}, 640-630 \mathrm{~m}$, MNHN No. P1-CIO-3, as C. gelatinosa (?), described by Monniot (1969), 1 spec. Thalassa St. W392, Sud Golfe de Gascogne, MNHN No. P1-GIO-4, as C. gelatinosa, 1 spec. Thalassa St. Z435, MNHN Nos. P1-61, 62, 63, as C. gelatinosa, 1 spec. on 3 slides. Mediterranean, BMNH No. 1890-5-19-2, 1 spec. Adriatic Sea, BMNH No. 1898-5-7-292, 1 spec. Naples: BMNH No. 1926-9-18-1, 1 spec.; SMBL Rare No. 146, 1 spec.; aquarium or bottom of boats in the Staz. Zool. Napoli, April to July, 1974, Hoshino coll., 13 spec.; the same station, date unknown, presented by F. Bentivegna, 12 spec. Off N. E. Chios, Greece, 20 m, BMNH No. 1966-7-20-29, 1 spec. Villefranche, South of France, BMNH No. 1960-10-10-5, 1 spec.

Atlantic coast of North America. In the vicinity of Eastport, Maine, no data; AMNH No. 682, as $C$. sociabilis tenella; 13 spec., at least 4 of which are clearly identifiable with $C$. intestinalis, probably examined and referred to by Van Name (1945). Eastport, Maine, 1872; AMNH No. 740, as $C$. sociabilis ienella, one specimen probably referable to $C$. intestinalis, do.

Atlantic coast of South America. Argentina: R. V. 'Vema' St. V-17-72, 39 21'S, 61 08'W, May 19, 1961, $15 \mathrm{~m}$; AMNH No. 2271, as C. intestinalis forma costata, described by Millar (1970); 5 spec. Rio de Janeiro, Brazil, SMNH No. 217, Oct. 18, 1893, described by Michaelsen (1923), 13 spec.

Pacific coast of North America. Almanitos Bay, Long Beach, California, from the boat floats, June 1979; Ju-Shey Ho coll.; 10 spec.

Japan. Mone, Karakuwa, Miyagi Prefecture, Sept. 3, 1970; together with 1 spec. of C. savignyi; Hoshino coll.; 2 spec. Onagawa, Miyagi Prefecture, Aug. 5, 1976; together with 5 spec. of C. savignyi; Hoshino coll.; 5 spec. Yokohama Hbr, Dec. 26, 1902; BMNH No. 1907-9-1-15, as C. japonica; Owston coll.; 4 spec. In front of Sugashima Mar. Biol. Stat., Sugashima Is., attached to the cages, several meters deep, Feb. 18, 1981; together with 40 spec. of $C$. savignyi; Nishikawa coll.; 27 spec. Zaga, Ago Bay, from the oyster cages, Jan. 8, 1982; together with 7 spec. of G. savignyi; Ooishi coll.; 2 spec. Osaka Bay, attached to vertical plates, ca. $5 \mathrm{~m}$ deep, June 10, 1980; Fuse coll., 12 spec. Tan'nowa Hbr, Osaka Bay, June 14, 1977; Yamanishi coll.; 4 spec. Tanagawa, Osaka Bay, from floating buoy, Aug. 11, 1980; Otani coll.; 2 spec. Kawarazu, Toyo Gity, Seto Inland Sea, June, 1978; Ishikawa coll.; 3 spec. Noto Mar. Biol. Stat., Noto-Ogi, Noto Peninsula, from the tanks, Apr. 5, 1975; Nishikawa coll.; 2 spec.

Australia. Port Jackson, NSW, from bottom of HMS Alert; BMNH No. 1881-10-6-34-37; 1 spec. Swan River, W. Australia; BMNH No. 1962-1-12-26; 4 spec. Peppermint Grove, Swan River; BMNH No. 1962-1-12-27; 1 spec. All were described by Millar (1963).

New Zealand. Lyttleton Hbr, South Island, wharf pile, ca. 20 feet, June, 1965; deposited in the Zool. Dept., Univ. of Canterbury and presented by A.C. Harris; 28 spec.

Description: All the specimens examined in the present study are quite identical with the previous description of $G$. intestinalis given by Millar (1953) or of C. robusta by Hoshino \& Tokioka (1967). As mentioned previously, the individual variations are discernible in the test consistency (soft gelatinous to more or less leathery, though 


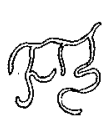

A

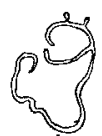

B

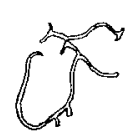

C

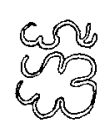

D

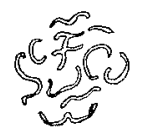

$\mathrm{E}$

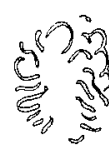

$\mathrm{F}$

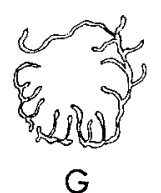

Fig. 1. Complicated ciliated groove in Ciona intestinalis (Linné) (A-C) and C. savignyi Herdman (D-G). A: $92 \mathrm{~mm}$ long specimen from California. B: About $165 \mathrm{~mm}$ long specimen from Naples. C: About $190 \mathrm{~mm}$ long specimen from Naples. D: $25 \mathrm{~mm}$ long specimen from Zaga, Japan. E: $49 \mathrm{~mm}$ long specimen from Sugashima, Japan. F: $64 \mathrm{~mm}$ long specimen from Onagawa, Japan. G: $67 \mathrm{~mm}$ long specimen from Sugashima, Japan. Enlarged to different scales.

not so hard and cartilaginous as once demonstrated by Hoshino \& Tokioka in some Japanese specimens of $C$. robusta; however, the test is so hard that the animal can be held upward in a single specimen from New Zealand). The mantle musculature usually consists, on each side, of 6 longitudinal bundles, 4 converging to the branchial siphon and 2 to the atrial, but the number and arrangement of the bundles may be sometimes variable in some degree; in addition to these there are nearly always a pair of longitudinal muscle fascicles along the midventral line. The size of pharyngeoepicardiac openings varies from minute to rather extensive, though this is partly due to artifact at fixation. The following additional notes may be noteworthy.

Rigidity of the test may be seemingly due mainly to its hardened thin surface layer, while the inner part is retaining more or less gelatinous consistency as already noted by Millar (1953, p. 9). Tentacles are usually well developed, ranging in number from ca. two dozens (in $8.5 \mathrm{~mm}$ long specimen from Plymouth) to 70 or more in larger specimens. Ciliated groove represented as a longitudinal slit in smaller specimens, while C-shaped sometimes with both horns rolled in, opened to the right side in the majority or anteriorly; it may be rather complicated in some larger specimens (Fig. 1, A-C). The endostylar appendage is usually very distinct, though rarely not so. Number of inner longitudinal vessels may seemingly change with growth as seen in Fig. 2. This figure may show that the specimens from Naples and the Japanese waters are somewhat different from those from northern European waters in the change rate of the number of inner longitudinal vessels with growth. Number of transverse vessels may increase with the body size, though rather difficult to be counted exactly; an example is given below in some specimens from Naples:

$\begin{array}{lc}16.5 \mathrm{~mm} \text { long individual } & 32 \text { vessels } \\ 30 \mathrm{~mm} & 46 \\ 36 \mathrm{~mm} & 60 \\ 43 \mathrm{~mm} & 70 \\ 81 \mathrm{~mm} & \text { ca. } 110 \\ 92 \mathrm{~mm} & \text { ca. } 130\end{array}$

The genital apertures are usually situated more or less far anterior to the anus which is located nearly in the middle of the branchial sac, in most cases opening at the level near the base of the atrial siphon. However, rarely they may be situated just close 
to the anus as seen in a specimen of MNHN No. PI-CIO-3 (see Monniot, 1969, p. 1135), or slightly anterior to it as in the specimens of MNHN No. P1-CIO-4 and ZMB No. 8578, and a specimen from Ingolf St. 9. This feature may be reminiscent of C. mollis ever recorded from off California, 1100 fathoms deep (Ritter, 1907, p. 37) and $C$. antarctica from the Antarctic, 95 to $100 \mathrm{~m}$ deep (Monniot \& Monniot, 1983, p. 49). It is noteworthy that all of these specimens with the genital apertures close to the anus, but $C$. antarctica, came from the deeper waters. The distal end of vas deferens is, so far as the authors are aware, always pigmented orange in living animals; this colouration still remains in many formalin-preserved specimens examined in the present study. Male genital apertures range in number from 5(?) to 30 in the European specimens, while 14 to 26 in the Japanese ones, and are opening one on each ellipsoidal papilla at the distal end of vas deferens; seemingly no correlation between the number and body size.

Remarks: If the orange pigmentation at the distal end of vas deferens can be taken as a significant diagnostic character for $C$. intestinalis (but also see Remarks of $C$. savignyi), C. intestinalis var. sydneiensis described by Kesteven (1909) and C. intestinalis described by Brewin (1950) may safely be assignable to $C$. intestinalis defined here. According to their descriptions, "at its (=vas deferens) termination, just below anus, there is a brilliant vermillion swelling" (p. 285) in var. sydneiensis, and "oviduct-opening at base of atrial siphon, red and deeply lobed" (p. 348) in Brewin's intestinalis. The position of the "swelling" in the former seems, however, quite unusual for this species. It was tried to examine Kesteven's specimens that are probably deposited in the Australian Museum, but so far in vain. Further, according to the personal communication of Drs. A. Harris and R. A. Savill, Brewin's specimens might seemingly be lost. However, all the specimens from Lyttelton, New Zealand, where Brewin obtained her specimens, that were examined in the present study, are clearly identifed with intestinalis here defined. Consequently, var. sydneiensis and Brewin's intestinalis may be included in $G$. intestinalis defined here, though some doubts still remain.

Ciona intestinalis longissima Hartmeyer and C. intestinalis gelatinosa Bonnevie have been recorded from the Arctic and the boreal waters of the North Atlantic. These forms are both provided with the postabdominal extension of mantle body (see Ärnbäck-Christie-Linde, 1934, pp. 18-24; Van Name, 1945, pp. 162-163). Although Hartmeyer (1899, text-fig. L) showed the endostylar appendage in his original description of $C$. longissima, nothing was mentioned as to the feature of the pharyngeoepicardiac openings. Fortunately the last author was given a chance to examine 22 specimens of $C$. intestinalis longissima collected from Baffin Bay, 450-1200 m deep, that were described by Lützen (1959) and now are deposited at the Zoologiske Museum, $\mathrm{K} \phi$ benhavn. Their taxonomic morphology is as follows;

Test is thick, but soft, gelatinous, transparent and colourless except in the posterior part, where it is somewhat tough, nearly opaque and white or slightly yellowish white. The endostylar appendage is rather indistinct, while the pharyngeo-epicardiac openings are discerned near the base of the appendage, but usually very small. 


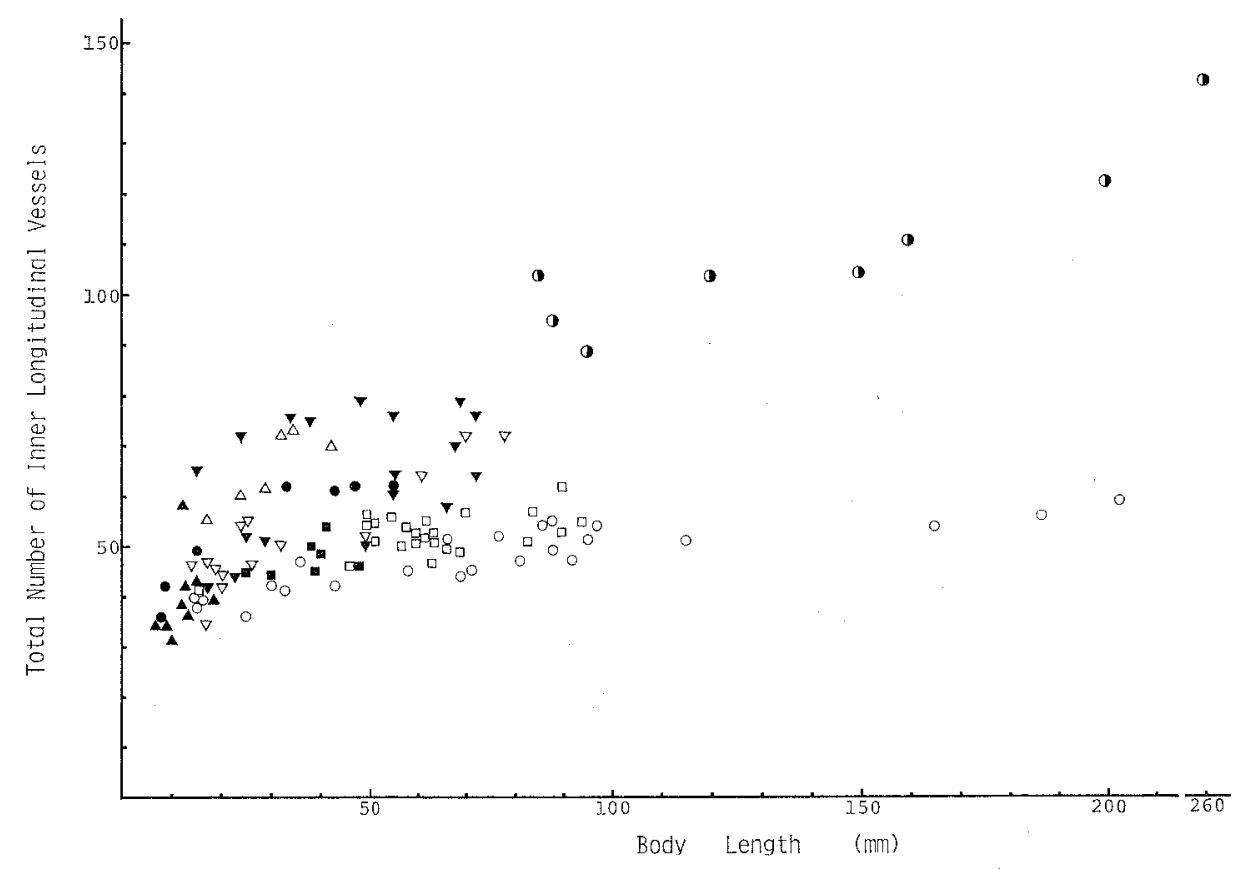

Fig. 2. Correlation between the total number of inner longitudinal vessels and the body length in the well-preserved specimens of Ciona intestinalis (Linné) from Greenland (solid triangle), Norway (inverted solid triangle), the Faroes and off the Shetlands (open triangle), Denmark and Western coast of Sweden (inverted open triangle), Plymouth (solid circle), Naples (open circle), Brazil (solid square) and Japan (open square), as well as those of Ciona intestinalis longissima from Baffin Bay (semi-open circle).

Genital apertures are situated anterior to, though not so far apart from, the anus; this feature may be reminiscent of the deep-water specimens of $C$. intestinalis mentioned previously (p. 67). Number of inner longitudinal vessels in well-preserved specimens is given in Fig. 2. This figure seems to suggest a closer relation between the specimens of longissima from Baffin Bay and the specimens of typical intestinalis from the boreal or the cold temperate waters as to the number of inner longitudinal vessels. Tentacles are much fewer than in typical intestinalis; up to 30-40 even in larger specimens. Number of male genital apertures ranges from 8 to 21 .

In addition, the last author also examined two specimens of "Ciona gelatinosa" deposited at the Zoological Museum, Oslo and registered as No. H212. These specimens, ca. $55 \mathrm{~mm}$ and $67 \mathrm{~mm}$ long respectively, were collected at St. 270 of "Nordhav Expedition" $\left(72^{\circ} 27^{\prime} \mathrm{N}\right.$ and $35^{\circ} 01^{\prime} \mathrm{W}$; June 30, 1878) and identified by Bonnevie, the author of this taxon. Neither of them can be the holotype, as the type was collected "on June 30 th, 1878 in $72.38^{\circ} \mathrm{N}$. Lat. and $33.50^{\circ} \mathrm{E}$. Long.-." (Bonnevie, 1896, p. 3). These specimens are of the following morphology:

Test thin but tough, translucent and white in alcohol. Mantle body much deteriorated, though postabdominal extension is clearly discerned. Endostylar appendage is very indistinct, while a pair of pharyngeo-epicardiac openings are 
barely discernible near the endostyle. Genital apertures are situated slightly (ca. $3.5 \mathrm{~mm}$ ) anterior to the anus, as the original description shows as "the oviduct-ending in a club-shaped body which extends a few millim. above the anus" (loc. cit.). Male genital apertures are about 20. Judging mainly from the position of pharyngeo-epicardiac openings, "longissima" and "gelatinosa" are considered to be closely related to $C$. intestinalis, but never to $C$. savignyi described below. Thus, longissima and gelatinosa are provisionally assigned in the present study to a subspecific rank in C. intestinalis.

Michibata, Vincentiis \& Gualitieri (1983) reported that in the content of vanadium $C$. intestinalis from Naples is quite similar to $C$. savignyi from Japan, but different from $G$. intestinalis from Japan, while in that of iron $C$. intestinalis from Naples resembles $C$. intestinalis from Japan. The taxonomic significance of the difference between the specimens of intestinalis from Japan and Naples is still an open question. Distribution: Europe, Atlantic coast of North and South America, Australia, New Zealand, California and Japan.

Ciona savignyi Herdman, 1882

(Fig. 1, D-G; Fig. 3)

Ciona savignyi-Herdman, 1882, pp. 236-237, pl. 35, figs. 1-2 (Kobe, Japan; RE); Traustedt, 1885, pp. 10-11 (without new records).

Ciona aspera --Herdman, 1886, pp. 416-418, pl. 49, figs. 11-13 (Kobe, Japan; RE).

Cima intestinalis -Ritter, 1913, p. 500 (Alaska: RE); Oka, 1935, pp. 464-466, fig. 35 (at least in part; Mutsu Bay, Japan; RE); Hoshino \& Tokioka, 1967, pp. 286-289, fig. 6 (left), fig. 8 (left) (Miyagi Pref,, Japan); Pisanó, Rengel \& Bustuoabad, 1971, figs. 1, 3, 6, 8-9 (Mar del Plata, Argentina); 1972, figs. 1 and 3 (Ibid.); Nishikawa, 1980, tab. 1 (Tanabe Bay and Sugashima Is., Japan).

?Ciona intestinalis - Tokioka, 1953, pp. 3-6, figs. 2-3 (in part; Seto Inland Sea, Japan; RE).

non Ciona savignyi --Roule, 1884, pp. 195-197, pl. 9, fig. 82 (Marseille).

Material examined:

Japan. About $1500 \mathrm{~m}$ off Shirogasawa, Shimokita Peninsula, Mutsu Bay, Aug. 11, 1926; OC No. 254 (M407); described by Oka (1935); 1 spec. Off Tsubakiyama, Mutsu Bay, July 17, 1927; OC No. N3 (M467); do.; I spec. Asamushi, Mutsu Bay, Aug. 3, 1975; Hoshino coll.; 3 spec. Mone, Karakuwa, Miyagi Pref., Sept. 3, 1970; together with 2 spec. of C. intestinalis; Hoshino coll.; 1 spec. Onagawa, Miyagi Pref., July 3, 1967 and Aug. 5, 1976; 10 spec. Tateyama, May 4, 1924; OC No. 325 (M365), as C. intesinalis; 1 spec. Enoura, Suruga Bay, Apr. 2-8, 1904; OC No. 387 (M113), as C. intestinalis; 6 spec. In front of Sugashima Mar. Biol. Stat., Sugashima Is., from cages, several meters deep, Feb. 18, 1981; together with 27 spec. of C. intestinalis; Nishikawa coll.; 40 spec. Zaga, Ago Bay, from oyster cages, Jan. 8, 1982; together with 2 spec. of $C$. intestinalis; Ooishi coll.; 7 spec. Off Kobe, $34^{\circ} 35^{\prime} \mathrm{N}$ and $135^{\circ} 10^{\prime} \mathrm{E}, 8$ and 50 fathoms, May 17-19, 1875; type specimen of $G$. savignyi; BMNH No. 1887-2-4-183. The same as the type locality of C. savignyi, 50 fathoms, May 19, 1875; type specimen of C. aspera; BMNH No. 1887-2-4-184. Inland Sea (=Seto Inland Sea), 8-15 fathoms, R. Gordon-Smith coll.; BMNH No. 1902-12-24-1-10, as Ciona sp.; 4 spec. Mukaishima Is., Seto Inland Sea, intertidal zone, Apr. 14, 1934; SMBL Rare No. 5, labelled as Ciona pulchella; 1 spec.; described by Tokioka (1953, pp. 4-6, fig. 3); posterior part of endostyle missing, but pharyngeo-epicardiac openings(?) barely discernible. Tsukumo Bay, Japan Sea, several meters, Aug. 20-21, 1975; Nishikawa coll.; 6 spec. Tsukumo Bay, 25 m, Mar. 17, 1976; Shin'ya et al. coll.; 18 spec. 
Off Tateishi, Wakasa Bay, $50 \mathrm{~m}$, June 16, 1981; Yasuda coll.; 1 spec.

Pacific coast of North America. Loring, Alaska, April 29, 1903; NMNH No. 5633; described by Ritter (1913); 1 spec. Stuart Is., British Columbia, on float, April 9, 1937; AMNH No. 1427, as $C$. intestinalis; 1 spec.

Description: The morphology of this species is given below in comparison with that of C. intestinalis:

1) Test soft, gelatinous, transparent to translucent and white. Hardening of the superficial layer of test as seen in $C$. intestinalis is usually indistinct. In some of old preserved specimens in alcohol such as the type specimens of $C$. savignyi and C. aspera, however, test is thin, transparent and white, but has become tough.

2) Tentacles are rather variable in number, but seemingly a little fewer than in C. intestinalis; never over about 50. In 19 specimens of $C$. savignyi, 35 to $75 \mathrm{~mm}$ long, and 15 specimens of $C$. intestinalis, 51 to $84 \mathrm{~mm}$ long, collected together on Feb. 18, 1981 in the vicinity of Sugashima, Japan, tentacles range from 11 (in $56 \mathrm{~mm}$ long specimen) to 38 (in $60 \mathrm{~mm}$ long one) in the former, while from 55 (in $62 \mathrm{~mm}$ long one) to 80 or more (in $94 \mathrm{~mm}$ long one) in the latter.

3) Ciliated groove simply C-shaped, or complicated (Fig. 1, D-G).

4) In the number of inner longitudinal vessels (Fig. 3), C. savignyi is similar to $C$. intestinalis from the Japanese waters or some parts of European waters (cf. Fig. 2). Transverse vessels in some specimens from Onagawa, Japan are:
$33 \mathrm{~mm}$ long specimen
ca. 90 vessels
$44 \mathrm{~mm}$
ca. 100
$64 \mathrm{~mm}$
ca. 160

5) Endostylar appendage completely absent.

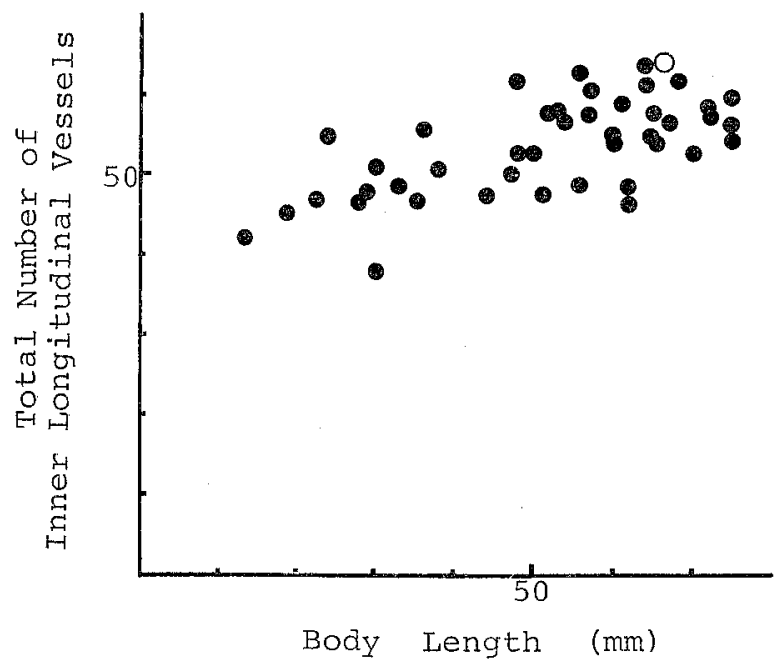

Fig. 3. Correlation between the total number of inner longitudinal vessels and the body length in the well-preserved specimens of Ciona savignyi Herdman from Japan (solid circle) and British Columbia (open circle). 
6) A pair of pharyngeo-epicardiac openings are situated close to the oesophageal opening.

7) Genital apertures are usually situated far anterior to the anus; in a $60 \mathrm{~mm}$ long specimen from British Columbia (AMNH No. 1427), however, they are located only slightly anterior to it.

8) Male genital apertures opening at the distal end of vas deferens, though never accompanied with any ellipsoidal papillae such as those seen in C. intestinalis (see p. 67). They range from 5(?) (in the type specimen of C. savignyi) to 20 (in a $52 \mathrm{~mm}$ long specimen from Wakasa Bay) in number, but seemingly less than in $C$. intestinalis. The distal end of vas deferens is, so far as the authors' limited observations of living specimens are concerned, never pigmented orange.

Remarks: According to the original description of $C$. aspera, "a red spot--placed on the extremity of the vas deferens, which is sometimes so conspicuous in Ciona intestinalis" (p. 418). This type specimen (BMNH No. 1887-2-4-184) is, in other features, quite identical with $G$. savignyi and, therefore, included in the synonymy of this species in the present study. The taxonomic significance of the pigmentation in the original description may be left in question.

Roule (1884) rccorded C. savignyi from Marseille. In spite of his carefulness to figure the endostylar appendage of $G$. intestinalis (pl. 3, fig. 29), he made no special references to this structure in his brief description of $C$. savignyi. This may suggest that Roule's C. savignyi was also provided with the appendage. If this is true, Roule's savignyi can never be assigned to $C$. savignyi defined here. The authors tried to examine Roule's specimens to confirm this supposition, but in vain. In such circumstances, it seems better to exclude Roule's savignyi from the synonymy of C. savignyi. Thus at present, European waters are seemingly inhabited only by C. intestinalis.

Distribution: Japan, Pacific coasts of Canada and Alaska, and Argentina.

\section{Brief History of Ciona intestinalis}

Linné (1767, p. 1087) firstly defined Ascidia intestinalis only as "A. (=Ascidia) laevis alba membranacea" and denoted as "Habitat in Oceano Europaeo", with bibliographical references to Bohadsch (1761), Baster (1760) and "Act. nidros." (=Gunnerus' paper published in 1765). Among these, Baster's species was later regarded as a doubtful junior synonym of Molgula manhattensis by Hartmeyer (1923, p. 66; but also see Hartmeyer, 1924, p. 93). The description of Bohadsch's "Tethyum fasciculatum" (p. 132, pl. 10, fig. 4) is never enough to determine its taxonomic identity. Gunnerus "gave a clear description of an ascidian species from Trondheimsfjorden which he named Tethyum sociabile" (Sneli \& Gulliksen, 1975, p. 127), but it cannot be supposed that the description may have information regarding the above-mentioned diagnostic characters requested now in the classification of Ciona; recently Sneli \& Gulliksen (loc. cit.) proposed the suppression of the name sociabile, validating the name intestinalis. The authors of the present paper have had no 

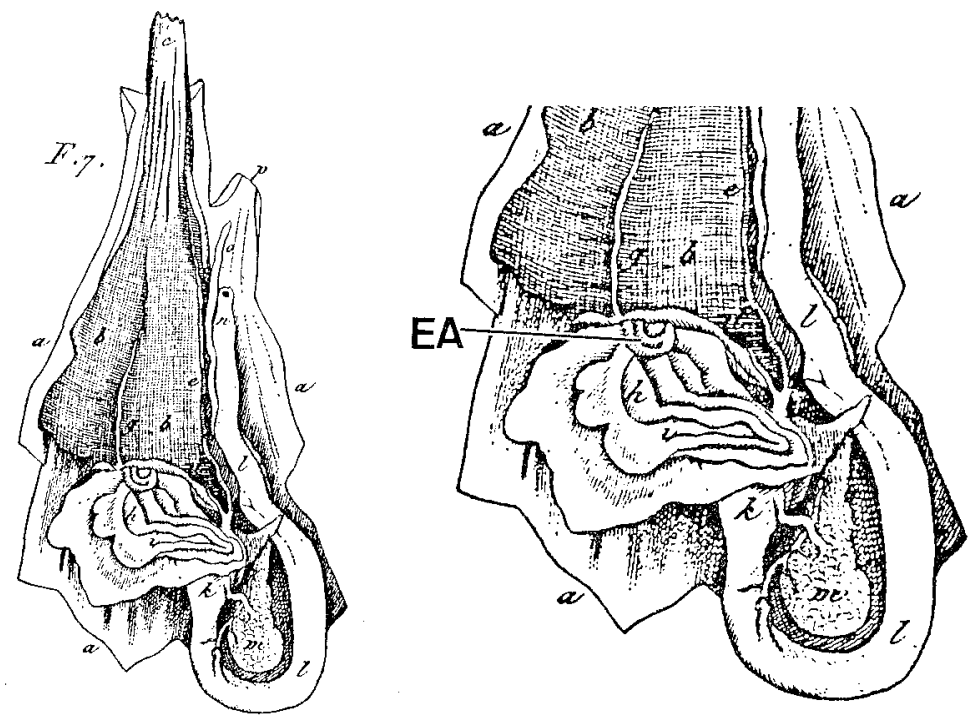

Fig. 4. Dissected mantle body of Ciona intestinalis from Europe, from Cuvier (1815, pl. 2, fig. 7), reproduced (left) or partly enlarged (right). Note the endostylar appendage (EA). See the text below.

opportunities to examine the type specimens of Bohadsch's, Baster's or Gunnerus' species up to now. And unfortunately enough, the type or other specimens of intestinalis examined by Linné himself are no longer found in the Swedish Museum of Natural History, Zoological Institute of Uppsala University or the Linnean Museum ( $\AA$. Franzén, person. comm.), nor in the Linnean Society of London so far as the first author inspected there. Thus it seems that the question cannot be answered primarily what may really represent $C$. intestinalis established by Linné. According to Alder \& Hancock (1907, pp. 6-7), Dominicus Vandelli well described and figured $C$. intestinalis in the year 1761 as "Holothurium laeve, dichotomum, fucis marinis alligatum". His figures, reproduced by them (fig. 27 on p. 8), show that his "Holothurium" is provided with 6 muscle bandles on each side of mantle body and very easily referable to the genus Ciona; however, they lack information completely as to the endostylar appendage and pharyngeo-epicardiac openings that are taken up in the present paper as the most important taxonomic clues.

Then in the literature, Guvier (1815) is the first to show the occurrence of the form of Ciona provided with the appendage (pl. 2, fig. 7; reproduced in Fig. 4 in the present paper), from European waters, and followed by many authors listed above. On the other hand, the other form, with the pharyngeo-epicardiac openings situated close to the oesophageal opening and without the endostylar appendage, has not yet been recorded there. However, this doesn't necessarily mean that the latter form has never inhabited European waters, for its diagnostic features may have been overlooked very easily. The possibility cannot be denied that the specimens referable to the latter form were confused with those of the former or clescribed 
under the other names else than intestinalis without sufficient information about these diagnostic characters. The authors have made their efforts to find out such specimens in any of European museums or other institutes, and were fortunately given chances to examine some of such specimens as shown above, though failed to meet a number of important specimens that were ever described by various authors under the specific name of intestinalis, as well as the type or any identified specimens of Ascidia corrugata O.F. Müller, 1776, A. viridescens Bruguière, 1789, A. membranosa Renier, 1807, A. virescens Pennant, 1812, Pleurociona edwardsi Roule, 1884, Ciona roulei Lahille, 1887 and C. intestinalis var. lutea Harant, 1928, all of which were recorded from Europe. All the specimens examined by the present authors are proved assignable to one of the two forms, which is provided with the endostylar appendage and the pharyngeo-epicardiac openings close to it and is defined as intestinalis in this paper; among them, the oldest ones were collected in 1861 .

On the basis of the results given by survey of the literature and actual examination of many specimens, it may well be supposed that European waters have been inhabited only by one of the two forms mentioned above. Thus, intestinalis of Linné should be automatically represented by that form with endostylar appendage and the pharyngeo-epicardiac openings near its base. This form was already described intimately and thoroughly by Millar (1953).

\section{Other Described Species of Ciona}

(1) The other form (=C. intestinalis sensu Hoshino \& Tokioka, 1967) was proved to be referable to $G$. savignyi Herdman, 1882 through the reexamination of the type specimen of this species. However, there remains a possibility that the specific name savignyi might be replaced in future according to the Law of Priority by the following three species of Ciona that were originated before 1882, but without any references to the above-mentioned diagnostic features: Ascidia ocellata Agassiz, 1850 and A. tenella Stimpson, 1852 from the North Atlantic coasts of North America, and A. tubifera Stimpson, 1855 from China. The first two were later synonymized with C. intestinalis by Hartmeyer (1903, p. 301), while the last was regarded as an uncertain species of the genus Ciona by Hartmeyer (1909-11, p. 1414). All these three species still remain uncertain as to their exact affiliation, because of the insufficient descriptions and (temporal?) missing of the type specimens.

(2) C. edwardsi - Very recently Ciona edwardsi (Roule, 1884) was redefined by Copello, Devos \& Lafargue (1981), basing on many specimens collected at a depth of up to $40 \mathrm{~m}$ at Banyuls-sur-Mer in the Mediterranean. By the courtesy of Dr. Lafargue, the last author of the present study examined four intact specimens of this species collected by Lafargue herself on August 31, 1983 at a depth of $30 \mathrm{~m}$ in the mentioned region. They were proved to share the main features with the above-mentioned species with the endostylar appendage. Brief description of these specimens will be made below.

In the four specimens mentioned above, body 78 to $124 \mathrm{~mm}$ long, attached to 
the substratum by left posterior half. Test soft, gelatinous and transparent in the anterior one-third of body, while rather tough, though not so hard, somewhat leathery and translucent in the rest. Mantle musculature consists basically of 4 longitudinal bundles converging to the branchial siphon and 2 bundles to the atrial on each side, and a pair of longitudinal muscle fascicles along the midventral line. Tentacles 21-35; ciliated groove as a simple C-shaped in the larger two specimens, while split into 2 (in $97 \mathrm{~mm}$ long specimen) or 5 (in $78 \mathrm{~mm}$ long one) simple pieces; endostylar appendage distinct; a pair of pharyngeo-epicardiac openings close to the endostyle; inner longitudinal vessels $45-47$ on each side; genital apertures situated more or less near the base of atrial siphon, and far apart from the anus located nearly in the middle of the branchial sac; male genital apertures, very lightly pigmented dark brown or yellow, opening one on each ellipsoidal papilla at the distal end of vas deferens, their number ranging from 15 (in $97 \mathrm{~mm}$ long specimen) to 26 (in the smallest one); gonad matured, eggs in oviduct about $200 \mu \mathrm{m}$ in diameter. These specimens examined are indistinguishable from $C$. intestinalis, only excepting that they are provided with markedly more inner longitudinal vessels than in C. intestinalis from any localities (ref. Fig. 2). The taxonomic significance of this difference, and then the specific distinctness of $C$. edwardsi may be better left pending here for the future studies.

(3) In addition to those described species mentioned above, several others have also been so far published under the generic name Ciona, such as flemingi Herdman, 1882, abdominalis Sluiter, 1898, indica Sluiter, 1904, mollis Ritter, 1907, antarctica Hartmeyer, 1911 and imperfecta Monniot et Monniot, 1977. Among these, $C$. abdominalis is clearly assignable to the genus Rhopalaea mainly on the basis of the feature of the branchial papillae (see Sluiter, 1898, pp. 8-10, pl. 1, figs. 3-8) as already so treated by Van Name (1921, pp. 370-372).

(4) C. flemingi and C. indica - Further, the last author recxamined the type specimens of C. flemingi (BMNH No. 1887-2-4-182) and C. indica (Zoological Museum in Amsterdam, TU 332; see Spoel, 1969, p. 163). The examination revealed that these two species may safely be referred also to the genus Rhopalaea. In these the thorax is clearly constricted off from the abdomen below it (though in the type specimens of flemingi the abdominal part is missing, the constriction is well illustrated in the figure 7 of plate 34 in the original description), the branchial papillae are almost (in flemingi) or utterly (in indica) indiscernible, instead of projecting so conspicuously from the mesial surface of inner longitudinal vessels as in $C$. intestinalis and $C$. savignyi, though clearly denoted as such in their original descriptions (Herdman, 1882, p. 235, pl. 34, fig. 8; Sluiter, 1904, p. 25, pl. 4, fig. 2). The thoracic musculature consists of about a dozen longitudinal bundles in the former or 20 in the latter, markedly ramified posteriorly on either side. On the other hand, another type specimen of Ciona indica collected at a depth of $274 \mathrm{~m}$ in the Flores Sea (Zoological Museum in Amsterdam, TU 333) differs utterly from both the original description of the species and the type specimens registered as TU 332 mentioned above. In the specimen from the Flores Sea, approximately $21 \mathrm{~mm}$ long and 14 
$\mathrm{mm}$ thick and with $11 \mathrm{~mm}$ long posterior extension of test, the mantle body is strongly contracted and rather heavily injured in former examination, and therefore, close reexamination was impossible. It is obvious, however, that the present specimen may safely be assignable to the genus Ciona in that it shares such generic features as the body never divided into thorax and abdomen, the mantle musculature consisting mainly of thick longitudinal bundles, the apparent existence of "perivisceral cavity", the characteristic position of heart and pericardium as well as the structure of gonad. Nevertheless, the present specimen is quite different from $C$. intestinalis and $C$. savignyi in the structure of branchial sac. In this specimen, the inner longitudinal vessels are supported above the sac surface by tall branchial papillae at or near their distal tip; thus the tips of papillae are never projecting out markedly beyond the vessels. In contrast with this, in $G$. intestinalis and $G$. savignyi the vessels are located virtually on the sac surface and large and conspicuos papillae are mostly projecting out beyond the vessels. In the specimen in question, tentacles about 20 , ciliated groove as an oval opening elongated longitudinally, inner longitudinal vessels about 40 or more on each side, endostylar appendage indiscernible, a pair of pharyngeo-epicardiac openings (?) situated close to the posterior end of endostyle, and genital apertures opening adjacent to the anus. Further affiliation of this specimen from the Flores Sea may be better left pending at present till more material is available in future. C. indica was also recorded from Sagami Bay, Japan by Hartmeyer (1906, p. 26), with brief description. The authors tried to examine those specimens of Hartmeyer, probably deposited in the Museum für Naturkunde, Berlin; unfortunately, however, Dr. D. H. H. Kühlmann of the museum kindly showed them that these specimens are not found there.

(5) Ciona mollis, ever recorded from off California, 1100 fathoms deep, may seemingly be very closely related to $C$. intestinalis and $C$. savignyi. Ritter's original description (1907, pp. 36-39) can not be brief, but lacks completely the information regarding the endostylar appendage and pharyngeo-epicardiac openings. As the type material is now kept in neither American Museum of Natural History nor National Museum of Natural History, Smithsonian Institution, the real taxonomic status of this species remains uncertain.

(6) Ciona antarctica was established by Hartmeyer (1911, pp. 471-472), basing on two specimens collected at a depth of $350 \mathrm{~m}$ and $385 \mathrm{~m}$ respectively in the Kaiser Wilhelm II Land, Antarctic Sea, but without any information about the abovementioned diagnostic features either. The authors have not yet been given a chance to examine the type of this species. Very recently Monniot \& Monniot (1983, pp. 47 and 49) rediscovered this species from the western coast of the Antarctic Peninsula, 95-100 $\mathrm{m}$ deep. Though their description also lacks the same information, $C$. antarctica may seemingly be somewhat different from $C$. intestinalis and $C$. savignyi in that the ovary is flattened, leaf-like and more or less diffused, instead of usually forming a compact pear-shaped mass in the latter. Conclusive taxonomic discussions on $C$. antarctica may be left pending at present. On the other hand, C. imperfecta, recorded from NE Atlantic, 3992-4300 $\mathrm{m}$ deep, by Monniot \& 
Monniot (1977, pp. 698-700), is obviously unique.

(7) In conclusion, the present authors are of the opinion that at least the following taxa belonging to the genus Ciona (sensu Monniot \& Monniot, 1973, p. 33) may be taken as certain and valid ones at present:

A) Provided with endostylar appendage, and pharyngeo-epicardiac openings situated neat it.

a) Without postabdominal extension of mantle, but very young animals.

G. intestinalis (Linné, 1767) (=G. robusta Hoshino et Tokioka, 1967)

b) With postabominal extension of mantle even in adults.

C. intestinalis longissima Hartmeyer, 1899

C. intestinalis gelatinosa Bonnevie, 1896

B) Without the appendage, and the openings situated near the oesophageal opening.

C. savignyi Herdman, 1882 (=C. aspera Herdman, 1886;

C. intestinalis sensu Hoshino \& Tokioka, 1967)

G) Abyssal species.

C. imperfecta Monniot et Monniot, 1977

D) Antarctic species.

C. antarctica Hartmeyer, 1911

\section{Acknowledgement}

The authors would like to express their sincere thanks firstly to Dr. Takasi Tokioka, Professor Emeritus of Kyoto University, who gave them precious advices, encouraged them consistently and so kindly read the manuscript critically, and to Dr. Hitoshi Michibata, Toyama University, for frequent, stimulating and helpful discussions. Hearty thanks are also due to the following persons who gave them the chances to examine the specimens and/or important information: Ailsa. M. Clark (British Museum (Natural History)), Erik Rasmussen (Zoologiske Museum, Kobenhavn), Åke Franzén (Swedish Museum of Natural History), P.S. Davis (Hancock Museum), Claude Monniot (Muséum National d'Histoire Naturelle), Harold S. Feinberg (American Museum of Natural History), Linda Cole (National Museum of Natural History, Smithsonian Institution), Bj申rn Gulliksen and Kjell M. Dorås (Trondheim Marine Biological Station, University of Trondheim), Endre Willassen (Zoological Museum, University of Bergen), Marit E. Christiansen (Zoological Muscum, University of Oslo), Claus Nielsen (Marine Biological Laboratory, University of Copenhagen), J.E. Smith (Plymouth Laboratory of the Marine Biological Association), B.G. Gardiner (Linnean Society of London), A.C. Pierrot-Bults (Zoological Museum in Amsterdam), A.C. Harris (Otago Museum), R.A. Savill (Canterbury Museum), D.H.H. Kühlmann (Museum für Naturkunde, Berlin), Peter Dohrn, Alberto Monroy, Flegra Bentivegna and other members (Stazione Zoologica di Napoli), Françoise Lafargue (Laboratoire Arago, Université de Paris), Ju-Shey Ho (California State University), Armando Pisanó (GONICET, R. Argentina), Reiji Hori (National University of Singapore), Noriyuki Satoh, Takuya Deno and Hiroki Nishida (Kyoto University), Shigeko Ooishi (Mie University), Shin-ichiro Fuse (Seto Marine Biological Laboratory), Ryohei Yamanishi (Osaka Museum of Natural History), Masaru Ishikawa (Ehime University), Tohoru Yasuda (Fisheries Experimental Station of Fukui Prefecture) and Michio Ootani (Osaka). The first author is indebted to Dr. Tetsuo Seki and other members of Oyster Research Institute, Karakuwa, and to Dr. Kiyoshige Sekino and others of Fisheries Laboratory, Tohoku University for their generous welcome and kind help in collecting specimens. The last author is also indebted to Drs. Koichi Sekiguchi and Tetsuo Iwami and Mr. Muneo Michikawa, 
University of Tsulsuba, who kindly gave him every facility for the examination of the ascidian collection of the late Dr. Asajiro Oka, to Mr. Tsutomu Shin'ya and other members of Noto Marine Biological Station, Kanazawa University, Dr. Hidemi Sato and others of Sugashima Marine Biological Station, Nagoya University and Dr. Eiji Harada and others of Seto Marine Biological Laboratory, Kyoto University, all afforded the author every facility during his stay, and to the Embassy of Sweden in Japan for information about the Swedish Museum of Natural History. This work is supported in part by Grants-in-Aid from the Ministry of Education, Science and Culture of Japan to the last author (Nos. 57740416 and 58740371).

\section{References}

*) Cited indirectly.

Alder, J. 1863. Observations on the British Tunicata, with descriptions of several new species. Ann. Mag. Nat. Hist., ser. 3, 11: 153 173, pl. 7.

— \& A. Hancock. 1907. The British Tunicata, 2, Ray Society, London, 164 pp.

Ärnbäck-Christie-Linde, A. 1934. Northern and arctic invertebrates in the collection of the Swedish State Museum. XII. Tunicata, 4. Gionidae, Ascidiidae, Agnesiidae, Rhodosomatidae. K. Svensk. Vetensk. Akad. Handl. tredje ser., 13: 1-91, pls. 1-11.

*Baster, 1. 1760. Opunscula subseciva, observationes miscellaneas de animalculis et plantis quibusdam marinis, eorumque ovariis et er seminibus continentia, Harlemi.

Berrill, N.J. 1950. The Tunicata with an account of the British species. London. $354 \mathrm{pp.}$

Bohadsch, J.B. 1761. De quibusdam animalibus marinis, eorumque proprietatibus, orbi litterario vel nondum vel minus notis, liber. Dresdae.

Bonnevie, K. 1896. Ascidiae simplices og ascidiae compositae fra Nordhav Expeditionen. Norske Nordhav-Exped., 7 (23): 1-16, pls. 3-4.

Brewin, B.I. 1950. Ascidians of New Zealand. Pt. IV. Ascidians in the vicinity of Christchurch. Trans. Roy. Soc. N. Z., 78: 344 353.

Copello, M., L. Devos \& F. Lafargue. 1981. Ciona edwardsi (Roule, 1884) espèce littorale de Méditerranée distincte de Ciona intestinalis Linné, 1767. Vie Milieu, 31: 243-253.

Cuvier, G. 1815. Mémoire sur les ascidies et sur leur anatomique. Mém. Mus. Hist. Nat. Paris, 2: 10-39, pls. 1-3.

Damas, D. 1899. Les formations épicardiques chez Ciona intestinalis (L.) Arch. Biol., 16: 1-25, pls. 1-3.

*Gunnerus, J.E. 1765. Sфe-Pungen, (Tethyum sociabile) fuldstaendig beskreven. Skr. Selsk. Trondhjem, 3: 81-102, pl. 2 .

Hancock, A. 1870. On the larval state of Molgula: with descriptions of several new species of simple ascidians. Ann. Mag. Nat. Hist., ser. 4, 6:353-368.

Hartmeyer, R. 1899. Die Monascidien der Bremer Expedition nach Ostspitzbergen. Zool. Jahrb., Syst., 12: 453-511, pls. 22-23.

- 1903. Die Ascidien der Arktis. In Römer, F. and F. Schaudinn (eds.), Fauna Arctica, 3: $93-412$, pls. 4-14.

1906. Ein Beitrag zur Kenntnis der japonischen Ascidienfauna. Zool. Anz., 31: 1-30.

. 1909-11. Ascidien. In Bronn, H.G. (ed.), Klassen und Ordnungen des Tier-reichs, Leipzig, 3 (suppl.) : 1281-1773.

- 1911. Die Ascidien der Deutschen Südpolar-Expedition, 1901-3. Dtsch. Südpol. Exped., 12: 403-606, pls. 45-57.

- 1915. Alder und Hancock's Britishe Tunicaten-Eine Revision. Mitt. Zool. Mus. Berl., $7: 303-344$.

__ 1923. Ascidiacea, Part I. Zugeleich eine Übersicht über die arktische und boreale Ascidienfauna auf Tiergeographoscher Grundlage. Danish Ingolf Exp., 2 (6): 1-365.

- 1924. Ascidiacea, Part II. Danish Ingolf Exp., 2 (7): 1-275.

Heller, C. 1875. Untersuchungen über die Tunicaten des Adriatischen Meeres, II. Denk. Akad. Wiss., Wien, 36: 107-125, pls. 1-6. 
Herdman, W.A. 1882. Report on the Tunicata collected during the Voyage of H.M.S. Challenger during the years 1873-1876. I. Ascidiae simplices. Rep. Voy. Challenger, 6: 1-296, pls. 1-37.

- 1886. Report on the Tunicata. II. App. A. Supplementary report upon the ascidiae simplices. Rep. Voy. Challenger, 14:1-429, pls. 1-49.

Hoshino, Z., \& T. Nishikawa. 1983. A taxonomic revision of two ascidian species of the genus Ciona from Japan. Zool. Mag., 92: 661. (Abstract: in Japanese)

— - \& T. Tokioka. 1967. An unusually robust Ciona from the northeastern coast of Honsyu Island, Japan. Publ. Seto Mar. Biol. Lab., 15: 275-290, pl. 7.

Kesteven, H.L. 1909. Studies on Tunicata. I. Proc. Linn. Soc. N. S. W., 34: 276-295, pls. 25-26.

Kupffer, C.W. 1870. Die Stammverwandtschaft zwischen Ascidien und Wirbelthieren. Nach Untersuchungen über die Entwicklung der Ascidia canina (Zool. dan.). Arch. Mikr. Anat., 6: 115-172, pls. 8-10.

- 1875. Tunicaten. Ber. Komm. D. Meere, 1872-1873, Kiel, 2: 197-228, pls. 1-2.

Linné, G. 1767. Systema naturae (Ed. 12); 1 (2), Holmiae.

Lutzen, J. 1959. Sessile Tunicata (Ascidiacea). Medd. Grфnland, 81 (3): 1-49.

Michaelsen, W. 1923. Neue und altbekannte Ascidien aus den Reichsmuseum zu Stockholm. Mitt. Zool. St. Inst. Hamb., 40: 1-60.

Michibata, H. 1984. Comparative study on amounts of trace elements in the solitary ascidians, Ciona intestinalis and Ciona robusta. Comp. Biochem. Physiol. 78A: 285-288.

--, M. de Vincentiis \& R. Gualtieri. 1983. Vanadium and other metals in Neapolitan ascidian, Ciona robusta. Zool. Mag., 92:660. (Abstract: in Japanese)

- - \& I. Yamazaki. 1981. Comparative study on amounts of trace elements in Ciona intestinalis and C. robusta. Zool. Mag., 90: 696. (Abstract: in Japanese)

Millar, R.H. 1953. Giona. L.M.B.C. Memoires, 35: 1-122, pls. 1-19.

- 1963. Australian ascidians in the British Museum (Natural History). Proc. Zool. Soc. Lond., 141: 689-746.

- 1970. Ascidians, including specimens from the deep sea, collected by the R.V. "Vema" and now in the American Museum of Natural History. Zool. J. Linn. Soc., 49: 99-159.

Monniot, G. 1969. Ascidies récoltées par la ((Thalassa)) sur la peute du plateau continental du golfe de Gascogne (18-25 Octobre 1968). Bull. Mus. nant. Hist. nat., Paris, 2e sér., 41: 11311145.

—, \& F. Monniot. 1973. Clé mondiale des genres d'ascidies. Archs. Zool. exp. gén., 113: 311-367.

—_ \& 1977. Tuniciers benthiques profonds du Nord-Est Atlantique résultats des campagnes Biogas. Bull. Mus. natn. Hist. nat., Paris, 3e sér., 466, Zool,, 323: 695-719.

-,$\&-1983$. Ascidies antarctiques et subantarctiques: morphologie et biogéographie. Mém. Mus. natn. Hist. nat., Paris, sér A, Zool., 125: 1-168, pls. 1-7.

Nakauchi, M., \& T. Kajiwara. 1978. On the ascidian, Ciona robusta and Molgula manhattensis. Zool. Mag., 87: 541. (Abstract: in Japanese)

Nishikawa, T. 1980. Ascidians from the coast of Kii Peninsula, Middle Japan, with descriptions of two new species. Mem. Natn. Sci. Mus., Tokyo, (13): 97-111.

Oka, A. 1935. Report of the biological survey of Mutsu Bay 28. Ascidiae simplices. Sci. Rep. Tohoku Imp. Univ., 10: 427-466.

Pisanó, A., \& D. Rengel. 1972. Comparative observations about self-fertilization in Ciona intestinalis and Ciona robusta in Mar del Plata (Argentina). Acta Embryol. Exp., 1972, 323-332.

- - \& O. Bustuoabad. 1971. Finding of Ciona robusta in Argentine Seas. Ann. Inst. Mus. Zool. Univ. Napoli, 19 (9): 1-10.

- - - 1972. Una ascidia todavia no señalada para Mar del Plata. Physis, 31: 179-183.

Ritter, W.E. 1907. The ascidians collected by the United States Fisheries Bureau Steamer Albatross on the coast of California during the summer of 1904. Univ. Calif. Pub1. Zool., 4: 1-52, pls. $1-3$.

- 1913. The simple ascidians from the northeastern Pacific in the collection of the United States National Museum. Proc. U. S. Nat. Mus., 45: 427-505, pls. 33-36. 
Rosati, F., \& R. De Santis. 1978. Studies on fertilization in the ascidians. 1. Self-sterility and specific recognition between gametes of Ciona intestinalis. Exp. Cell Res., 112: 111-119.

Roule, L. 1884. Recherches sur les ascidies simples des côtes de Provence. I-Phallusiadées. Ann. Mus. Hist. nat., Marseille, 2: 7-270, pls. 1-13.

Savigny, J.G. 1816. Mémoires sur les animaux sans vertèbres. Part 2, fasc. 1, Paris, 260 pp.

Sluiter, G.P. 1898. Tuniciers recueilles en 1896 par la "Chazalie" dans la mer des Antilles. Mem. Soc. Zool. France, 11:5-35.

- 1904. Die Tunicaten der Siboga-Expedition. I. Die sozialen und holosomen Ascidien. Siboga-Exped., Monogr., 56a: 1-126, pls. 1-15.

Sneli, J.-A., \& B. Gulliksen. 1975. Tethyum sociabile Gunnerus, 1765 (Tunicata, Ascidiacea): proposed suppression under the Plenary Powers. Z. N. (S.) 2087. Bull. Zool. Nom., 32: 127-128.

Spoel, S. van der. 1969. Catalogue of the type specimens of Tunicata in the Zoological Museum in Amsterdam. Bull. Zool. Mus. Univ. Amsterdam, 1: 157-201.

Tokioka, T. 1953. Contributions to the Japanese ascidian fauna. V. Ascidians collected near the Marine Biological Laboratory of Hiroshima University in the Inland Sea (1). Publ. Seto Mar. Biol. Lab., 3: 1-25.

Traustedt, M.P.A. 1880. Oversigt over de fra Danmark og dets nordlige Bilande kjendte Ascidiae simplices. Vidensk. Meddel. naturh. Foren. Kbhvn, 1879-80, 397-443.

- 1882. Die einfachen Ascidien (Ascidiae simplices) des Golfes von Neapel. Mitt. Zool. Stat. Neapel, 4: 448-488, pls. 33-37.

- 1885. Ascidiae simplices fra det Stille Hav. Vidensk. Meddel. naturh. Foren. Kbhvn, 1884, 1-60, pls. 1-4.

Van Name, W.G. 1921. Ascidians of the West Indian region and southeastern United States. Bull. Amer. Mus. Nat. Hist., 44: 283-494.

- 1945. The North and South American ascidians. Bull. Amer. Mus. Nat. Hist., 84: $1-476$, pls. $1-31$. 